\title{
Exploring Literary Voices in The Lost Child
}

\section{Giovanna Buonanno}

\section{(2) OpenEdition}

1 Journals

Electronic version

URL: https://journals.openedition.org/ces/4499

DOI: 10.4000/ces.4499

ISSN: 2534-6695

\section{Publisher}

SEPC (Société d'études des pays du Commonwealth)

\section{Printed version}

Date of publication: 1 September 2017

Number of pages: 95-103

ISSN: 2270-0633

\section{Electronic reference}

Giovanna Buonanno, "Exploring Literary Voices in The Lost Child", Commonwealth Essays and Studies [Online], 40.1 | 2017, Online since 02 April 2021, connection on 24 January 2022. URL: http:// journals.openedition.org/ces/4499; DOl: https://doi.org/10.4000/ces.4499

\section{(c) (i) (3) $\Theta$}

Commonwealth Essays and Studies is licensed under a Licence Creative Commons Attribution - Pas d'Utilisation Commerciale - Pas de Modification 4.0 International. 


\section{Exploring Literary Voices in The Lost Child}

In The Lost Child (2015) Phillips weaves an intricate web of multiple stories that move in time from post-war Britain to the nineteenth-century Yorkshire setting of Emily Brontë's

Wuthering Heights, which is here imaginatively reworked. In this novel, it is also possible to trace the influence of the Caribbean writer Jean Rhys and references to aspects of Phillips's autobiography. This article discusses intertextuality in the novel and argues that literary refractions and the ensuing polyphony contribute to Phillips's ongoing project of critically engaging with the English cultural and literary heritage.

Caryl Phillips's novels are composed as fascinating "vocal kaleidoscopes" (Ledent, "Slavery" 281), refracting the characters' precarious lives that unfold across distant times and locations. The resulting polyphony in Phillips's broken narratives is frequently reinforced through several references to other writers' works, as well as to his own writing. As a writer who considers himself to be "the product of diaspora" (Schattemann 30), and acknowledges the "full complexity" of his "plural self" "Color Me English" 123), Phillips straddles multiple literary traditions rooted in various places, of which he is "both of, and not of" ("New World Order" 1). As Ledent has noted with reference to Higher Ground (1989), one of Phillips's earlier novels, the author digs into the European - most notably the English - literary canon, but also integrates Afro-American and Caribbean classics into his work. In this light, the intertextual traces that are suggestive of Phillips's cultural plurality and of his engagement with several literary antecedents, are not only part of a concern with "writing back" to canonical works, and with the use of counterdiscursive strategies, that often characterise the work of postcolonial writers, but also represent "a cross-cultural and thus potentially enriching process" (Ledent, "Intertextuality" 301-2). This intertextuality can be viewed as instrumental to the writer's project of mapping and rewriting the Black Atlantic, as "continually criss-crossed by the movement of black people - not only as commodities" (Gilroy 193) and allows him to reclaim literary texts belonging to various genres and traditions, that in more or less direct ways chronicle the lives of black people during transatlantic slavery or document their presence across the Atlantic in different epochs. Furthermore, Phillips's forays into literary archives respond to his search for identity as both a writer and a Black Briton: he has often expressed the difficulty he has faced in trying to find his place within the works of English literature and has referred to the power of literature to provide, as well as deny, a sense of identity. His early days as a literature student at Oxford sharpened his awareness of his problematic positioning, as he argues in The European Tribe: "If the teaching of English Literature can feed a sense of identity then I, like many of my black contemporaries in England was starving!" (2) However, as a writer he is also aware of writing "in the lee of a robust literary history" "Color me English" 123), a reflection that may account for his ongoing dialogue with other writers in the same tradition.

In this article, I will discuss the interpolation of multiple literary voices in the novel The Lost Child (2015), Phillips's most recent novel to date, and argue that literary 
refractions and the ensuing polyphony in the novel persuasively contribute to Phillips's ongoing project of revisioning English history and its cultural and literary heritage. The novel is a multilayered text, embedding various apparently distant narratives, and represents a crossroads at which several pre-texts meet, ranging from Wuthering Heights (1847), arguably the most direct source text - imaginatively revisioned so as to elaborate on the character of Heathcliff, as well as to draw in Emily Brontë as a character - to Phillips's own essays and testimonies drawing on his own experiences as a black child growing up in the north of England. What is more, Phillips pays tribute to the work of modernist writer Jean Rhys, whose influence he has often acknowledged, especially when he reveals his fascination for her "modernist excursions [...] into the fragility of particularly female psychology" (Clingman 5). Phillips considers Rhys to be one of several Caribbean writers who have contributed to orienting his literary development within a "triple heritage of journeying: British, Africa diasporan, Caribbean" ("Color me English" 125). Her influence can be variously traced in Phillips's novels, as the fragile female characters in Rhys's oeuvre grappling with loneliness, marginalisation and displacement, have, as has been noted, inspired some of Phillips's female characters, such as Leila in his debut novel The Final Passage (1985), or Irina in Higher Ground (1989). ${ }^{1}$ The Lost Child follows Rhys in her depiction of troubled female subjectivities, as will be argued later in this article, while also evoking Rhys's presence at a meta-fictional level, as the postcolonial "writer back" of Wide Sargasso Sea.

In The Lost Child, Phillips re-reads and rewrites canonical texts in somewhat oblique ways that recall his previous journeys through literature, such as The Nature of Blood (1997), a novel based on Shakespeare's Othello, or his reworking of Olaudah Equiano's 1789 Interesting Narrative, which provides a blueprint for Phillips's Cambridge (1991), as well as one of the sources for the novel Crossing the River (1993). In these earlier novels, Phillips also draws on sources from minor literary traditions and genres, such as memoirs and women's travel journals, which tend to reinforce the intertextual dimension in his work. When discussing The Lost Child, Phillips has stressed the significance of "the orchestration" of different narratives (Clingman 3), whereby stories reverberate into each other. Orchestration is the key to understanding the novel, since, by following various strands and reworking multiple sources, the author forges an "unpredictable narrative" (Clingman 3) that deals with the interconnected themes of loss, abandonment and troubled childhood.

\section{Lost Children in the English North}

In the "unpredictable narrative" of The Lost Child, Phillips weaves an intricate web of multiple voices and three stories that move in time, from the 1960s to the nineteenthcentury Yorkshire setting of Wuthering Heights. Brontë's work provides a major inspiration and a narrative framework, since both the first chapter and the two final chapters of The Lost Child together form the first story which creatively engages with the character of Heathcliff in Wuthering Heights and ultimately frames the other two stories in the novel. In it Phillips meta-fictionally imagines the story of young Heathcliff, before $\mathrm{Mr}$. Earnshaw - cast here as the boy's father - brings him home to his family. The second

1. On the affinities between female characters in Rhys's Voyage in the Dark and those in Phillips's Higher Ground, see Ledent, "Intertextuality"; on Rhys as an important influence in The Final Passage, see Ledent, Caryl Phillips. 
and longest story takes place in the 1960s and 1970s and chronicles the life of Monica Johnson, who struggles to bring up her mixed-race children as a single parent in the north of England. And a third and shorter narrative imaginatively recreates the last moments of Emily Brontë's life and her reflections on her family.

The three intersecting stories take place in Yorkshire, with a brief interlude in the city of Liverpool, which is the setting of the first frame introducing Heathcliff, and an equally brief spell in London in the story of Monica Johnson. Both rural and urban Yorkshire is the common setting for the narratives and helps to provide "subtextual unity" (Ledent, "Intertextuality" 302) to an otherwise fragmented novel, while emphasizing the strong relationship between place and identity. Ian Baucom has stressed the "identity endowing property of place" (4) and its role in projecting a sense of identity in literary interventions. Baucom suggests that

Englishness has been generally understood to reside within some type of imaginary, abstract or actual locale, and to mark itself upon that locale's familiars. Over the past 150 years the struggles to define, defend, or reform Englishness have, consequently, been understood as struggles to control, possess, order and dis-order the nation's and empire's spaces. (4)

Black British writing has endeavoured to defamiliarize narratives of English locales, disrupting their supposedly ethnic or cultural homogeneity, in order to present a more inclusive version of what it means to be English. Consequently, it has contributed to mapping out "spaces of instability within the geographies of Englishness" (Baucom 4), showing that a locale endowed with the nation's character is mutable as it is "occupied by living subjects as they visit, inhabit, or pass through it, leave their estranging marks upon it [...] and in so doing reveal England as continuously discontinuous with itself" (Baucom 5). Phillips's exploration of the North of England as a literary location helps to strengthen the awareness of his "northern soul" in shaping both his personal identity and his writing self. ${ }^{2}$

Wuthering Heights and its northern setting are obliquely evoked in the first story of the novel, where Phillips revisits the neo-slave narrative genre and confronts his readers with the horrors of the transatlantic trade and its legacy, by chronicling the plight of a formerly enslaved African woman. Her final passage across the Atlantic has taken her to "a clamorous town of ships and sailors" (Lost Child 10), only later identified as Liverpool, a bustling slave port city where men of commerce discuss the "fluctuating prices of sugar, rum, and slaves on the Exchange Flags" (250). Written as a third-person narrative of the destitute "Congo woman" in the elaborate, and slightly old-fashioned style the author chooses for his nineteenth-century narratives, the story sketches the woman's life moving between past and present, offering a vivid and harrowing depiction of her dual crossing: first her voyage from Africa to the New World and then from there to England, "her third homeland in a lifetime" (6) where, on arrival, "a forthright working woman" makes it "her objective to help this lost soul reclaim her grit" (10). Her liaison with a white man burdened "with inconvenient wife and children" (7) produces a boy who, seven years on, acts as care-giver and sole comfort to his ailing mother. However,

2. The north of England is evoked in the essay "Northern Soul" (2005), a tribute to Phillips's hometown, Leeds. He reflects on the transformation of the city with "cobbled streets [...], dark gloomy buildings [...] and pubs that still operated a colour bar," that "took [his family] in, back in 1958," and notices that it has acquired over the years a more cosmopolitan, multiracial outlook ("Color me English" 122). 
due to the "taint in his offspring's breeding" (10), the gentleman progressively estranges himself from both mother and child. The uncertain fate of the unnamed child lingers throughout the whole book and is fully disclosed only in the closing chapter. Phillips captures the problematic positioning of a black child in pre-abolition Britain, in the words of the boy's anxious mother, recalling the iconography of blackness in paintings of the period:

... No. no. no. She has seen the other boys, ornately attired in silks, with silver collars and satin turbans, walking behind fair ladies so they might attend to their mistresses' trains, or quickly administer smelling salts, or take charge of their fans. But other boys, not her child. (6)

When, in the closing chapter of the novel, the gentleman returns as Mr. Earnshaw, determined to take the boy home with him and colour him English, the fate of the boy with a "strong and tenacious heart" (6) takes a different turn and the narrative becomes a prequel to Wuthering Heights, blurring the boundaries between original and rewriting, source and target text. And the book ends with father and child braving the elements as they head "home." Phillips dwells on the inhospitable moors, ravaged by a storm "with volcanic anger" (257) and captures the boy's distress, his longing for his mother and his reluctance to be with "the wispy-haired man" and in this unfamiliar place, as if to prefigure the difficulty Heathcliff would face in entering a different story and inhabiting Brontë's narrative. But the boy's uncomfortable relationship with the moors resembles that of the other black boy characters of the book, who in the second parallel story set in modern times, can never feel properly at home in the same setting. Like other "foreigners" and marginalized characters in Phillips's writings, this boy "inscribes an opening onto alterity" (Calbi 53), as he stumbles and "loses his footing" (260) in the open, transitional space of the Yorkshire moors.

Phillips then suggests that Heathcliff is the product of the triangular trade, of the mobility and traffic of colonial/imperial Britain, a literary figure that hides the uncomfortable truths of imperial history behind his exotic, dark-skinned gypsy looks. In Wuthering Heights, Heathcliff makes his entrance in the Earnshaw household as a dirty, ragged, black-haired child, "as dark almost as if it came from the devil" (77), who can only speak "some gibberish that nobody could understand" (77). The starving, houseless boy Mr. Earnshaw decides to pick up from the Liverpool streets, after having "enquired for its owner," functions as a replacement gift both for the children, since the presents originally intended for them were damaged or lost, and for Mrs. Earnshaw, who immediately dislikes the "gipsy brat" (77). As Susan Meyer has argued, Heathcliff is a character subjected to the "potent gaze of a racial arrogance deriving from British imperialism" (97), manifested in the description Mr. Linton gives of him as the "strange acquisition" Mr. Earnshaw made in Liverpool, "a little Lascar, or an American or Spanish castaway" (91). ${ }^{3}$

By placing Heathcliff firmly within the history of transatlantic slavery with his rewriting, Phillips fills the gaps of Wuthering Heights and solves the riddle of the character's unknown origin, while expanding "the novel's horizons overseas and across

3. Phillips admits to his long-time fascination with Heathcliff and reveals his wish to write about him, partly to challenge alternative readings of this character, such as Terry Eagleton's view of the boy as Irish (see Clingman 5-6). Heathcliff is cast as black and confronted with overt racism within the Earnshaw household in Andrea Arnold's filmic adaptation of Wuthering Heights released in 2011. 
centuries" (Smith, "Review" online). He does this in ways that recall Jean Rhys's take on Jane Eyre, aiming to solve the riddle of Bertha Mason's life before her confinement in Thornfield Hall, while unpacking the colonial implications of Charlotte Brontë's novel. The presence of Heathcliff looms over the whole book, bringing with him a sense of mystery and transferring some of the gothic atmosphere of Wuthering Heights onto other parts of the novel. Furthermore, it provides the author with the opportunity to explore familiar issues relating to belonging, exclusion, loss and the absence of fathers that are a signature of his work.

In The Lost Child the boy's troubled childhood, suspended between his dying black mother and his elusive white father, is refracted in the story of two mixed-race children growing up in Yorkshire in the 1960s and 1970s. For this section, Phillips delves simultaneously into his own personal archive as a black boy growing up in Leeds, and that of Yorkshire local history, recalling a real case of serial killings in the 1960s and conjuring a dark side of the northern soul. In this second story Phillips focuses on Monica Johnson, a promising Oxford student from Yorkshire (like Phillips was himself) who decides to drop out during her second year, in order to marry the mature, politically engaged Ph.D. student Julius Wilson, who comes from an unnamed Caribbean country. Monica is a significant addition to the composite gallery of Phillips's female characters, who, like immigrants or black characters, often perform the role of outcasts and outsiders in his writings. In many ways, she reflects the story of the lonely and destitute slave woman of the first narrative; but, as a bright and fragile woman, who is a librarian and nurtures a secret passion for writing, she also anticipates the figure of Emily Brontë sketched in the third narrative of The Lost Child. Monica also embodies a rebellious spirit, a woman who, like other characters in Phillips's oewure, is able to "cross the river" of racial prejudice: she is initially drawn to Julius as a form of rebellion against her authoritarian father ("I came to you, Julius, because I thought you might be a better kind of man than my father" [51]). Her decision to marry someone "who originated in a part of the world where decent standards of behaviour and respect for people's families were obviously alien concepts" (22) is unacceptable to her father and Monica is forced to sever her links with her family, thus becoming herself one of the several lost children in the narrative. Even when Monica relocates up north from London with her children, after the breakup of her marriage, she fails to reconnect with her parents and her situation gradually deteriorates.

The story of the black Heathcliff is variously reflected in both of Monica and Julius's children, Ben and Tommy Wilson. By refracting the Heathcliff character in the two boys, Phillips explores in detail their emotional suffering as they grow up with an absent father and a progressively unstable mother. Their story details the isolation, abandonment, the racial prejudice they suffer at school and the neglect they experience in their foster families. Tommy, the younger of the two, is the one most affected by the situation, and, in fact, is described through his brother's eyes as a perennially hungry child, like the starving Heathcliff: "It seemed like he was always starving, which didn't make any sense as Mam always wrapped us both some dinner money in pieces of paper and left it for us on the kitchen table" (144). Tommy's hunger conceals his desire for affection and acceptance, and a longing for his father: "Tommy always wanted to talk about the same thing. How come our dad never came to see us? Didn't he care for us anymore?" (146) The boy's emotional instability and desire for a father figure finally 
take a tragic turn as "our Tommy" fails to return home "one stormy night" (172) after football training, an event recounted through Ben's eyes. The tragic destiny of the child remains wrapped in mystery, as the circumstances of his end are not openly revealed and the feared, horrific murder is reported but not seen. ${ }^{4}$ In one of the most heartwrenching scenes in the novel, that conjures up images of Heathcliff calling out for Catherine in Wuthering Heights, a deeply distressed Ben wanders on the moors a few years after his brother's disappearance crying out his name:

I stopped by the side of the road and stared at the depressing landscape. [...] It must be pitch black up here at night. And cold, and our Tommy didn't have his duffel coat with him. I shouted. Tommy! [...] Tommy! Tommy! But it was no use [...]. I took a few steps onto the actual moorland. [...] I wasn't ready to abandon our Tommy again. (189)

Following the boy's disappearance, the family falls apart, as Monica's mental health deteriorates and Ben is moved to a foster family. Links with the young Heathcliff of the first story are resumed towards the end of the novel, when Ronald, Monica's father, decides to "act decisively" (203) and travels to reconnect with his grandchild Ben, now a university student, offering as an excuse his decision to return Monica's letters and writings to the boy, thus recalling Mr. Earnshaw's journey to bring Heathcliff home. However, the encounter is fraught with a lack of communication and Ronald can only vaguely hope that in the future "the boy may contact him" (209).

\section{(Auto)biographies and Literary Genealogies in The Lost Child}

The events in the boys' lives, both before and after Tommy disappears, are orchestrated in ways that suggest links with Phillips's own life experiences, previously recounted in some of his essays. According to Louise Yelin, Phillips disseminates his works with traces of his own life: the author's autobiographical impulse can be traced in several of his essays, as well as in works such as Foreigners: Three English Lives (2007), where he represents himself "by writing about others" (Yelin 59). However, as features of his childhood and adolescence make their way into The Lost Child, the author's project of an "autobiography of the other" (70) expands to also encompass his fiction. The author makes use of material already assembled in the collection Colour Me English (2011), such as the opening essay of the same title, where he recounts memories of him and his brothers being the only black boys, first at the local primary school and then at grammar school. In this text, he reflects on his precarious position of being "exposed" ("Color" 7), as the English could see him and decide to accept him on the sports ground, for instance, but he is aware that this kind of privilege could be "withdrawn" (7). In The Lost Child, this feeling is transferred to Tommy, when he arrives in the new school, looking "pathetically out of place" (115), and is immediately exposed and subjected to the racial prejudice of both teacher and schoolmates:

\footnotetext{
"Well, stand up, young man, and tell us your name and where you are from"

$[\ldots]$

"My name is Tommy Wilson"

"And where are you from, Thomas?"

"I'm from England."
}

4. In writing about Ben's disappearance, for which Monica's lover Derek Evans is charged, Phillips draws on the 1960s Moors murder cases, when a number of young people were killed and buried in the Moors by a local couple (Clingman 2). 
His fellow pupils release a volley of scornful cackling that threatens to swell into hysteria. (117)

Later in the novel, in a lengthier chapter entitled "Childhood" and written as Ben's first-person narrative, that largely focuses on Ben's coming of age, Phillips arranges the events in ways that recall his short autobiography "in ten chapters" from childhood to adulthood, described in an earlier essay. In "A Life in Ten Chapters" (Color Me English 107-12), Phillips frames the development of his plural reader/writer self by sketching ten brief entries, each associated with a book he has read at a particular moment in his life, till the very last one, where he himself is the author of two books. Deploying a very similar strategy, Phillips chronicles Ben's life through equally short sections, each one named after the title of a song or a film he can relate to a stage in the boy's life. The chapter makes reference to an array of pop music icons and film stars, conjuring an alternative world to comfort the lonely boy, just as the boy in "Ten Chapters" finds solace in the rather solitary activity of reading.

By layering the figures of Heathcliff with the Wilson boys as well as with himself, Phillips maps a complex autobiography of the other. The boundaries of this supposed autobiography stretch even further, as the author brings into the narrative the literary figure of Emily Brontë. In the apparently disconnected and broken narrative revolving around Emily Brontë, Phillips reveals his interest in the writer's biography, whose life is here imaginatively recreated, while adding another strand to the main theme of the lost child across time and space which is dealt with in the novel. Emily's story allows for a further exploration of the contested father-child relationship, as it mostly dwells on the Brontës' family context and the children's relationship with their authoritarian father, following the tragic death of Emily's brother Branwell. An ailing Emily remembers the conflict between father and son, and the gap between the two that "widened by expectation and disappointment. The one feeding the other" (105). As in the MonicaRonald relationship, Branwell Brontë is bound to introduce "failure into the world of his father," having chosen "to make a sanctuary of the Black Bull [pub]" (107). In a passage that resembles Ronald's withdrawal from Monica, Emily mourns her lost brother, and recounts how he, ravaged by alcohol and oppressed by debts, was finally rejected by their father: "Poor Branwell, [...] Papa made it clear to Branwell that there would be no further sympathy or help, which served only to further stoke the fires of resentment between them" (107). However, as a foil to the harsh father-child relationship in the family, Phillips imagines a stronger and more intimate bond between Emily and her sister Charlotte, her "dear Charlotte" (111) who cares for her, thus refracting in the two sisters the affectionate relationship between Ben and Tommy.

By casting Emily Brontë as a character in the novel, Phillips admittedly intends to resume "his unfinished business" with the writer, after his "clumsy tribute" to her in his novel Cambridge, where Brontë provides a model for the character of Emily, an "isolated, out of place, vulnerable, but clearly very smart" woman (Clingman 6). Phillips largely resorts to the rather conventional iconography of the ailing, reclining Victorian woman in his portrait of Emily in The Lost Child, but nonetheless manages to evoke Brontë's powerful literary influence as the author of Wuthering Heights and, what is more, as the creator of the puzzling figure of Heathcliff that, as Phillips imagines, continues to haunt Emily in her last days. In her troubled reveries, Emily blurs the boundaries between life and fiction as she juxtaposes the memory of Heathcliff with that of her 
own brother. She recalls "the strange boy with blazing eyes who had lost his place in the world" and was brought into her own family, as a gift offered to them by their own father: "Papa] unwrapped the boy from his cloak like a gift he wished to share" (110), a reminder of Heathcliff's position in Wuthering Heights as both a "gift" and a "strange acquisition."

The cameo role Emily plays in the narrative brings the significance of tracing and braiding literary affiliations into focus. Phillips complicates literary genealogies and moves with ease between England and the Caribbean, by engaging also with Jean Rhys's work. Rhys somehow haunts The Lost Child, in the sense that Phillips's reworking of Wuthering Heights can be placed next to the Wide Sargasso Sea's rewriting of Jane Eyre, one that became a blueprint for subsequent postcolonial interventions in the English literary canon. Even though Phillips acknowledges the role of Rhys as the author of Wide Sargasso Sea in mobilizing the English literary canon, he has said that it is not his favourite text in Rhys's oeuvre and admits to being drawn more to her other works (Clingman 5).

Rhys is a writer whose work is "a crossroads of powerful literary forces: those of Caribbean literature, modernism, women's writing and emergent postcolonial literatures" (Emery i). Furthermore, her works expose "the complex dynamics linking modernism and imperialism" (ibid.). As an "extravagant stranger," she creates challenging characters in both her novels and shorter fiction, a gallery of women seen by Phillips as "lonely, alienated, unwanted female figure(s), battling against the forces of class and culture" ("Extravagant Strangers" 63). One such character is at the centre of Rhys's short story "Let Them Call It Jazz" (1960), a text that is woven into the fabric of The Lost Child and re-enacted in a chapter depicting Monica Johnson's final demise.

Rhys chronicles the daily troubles of Selina Davis, a Caribbean woman in London, seeking employment as a seamstress, who, after her savings have been stolen and she is accused of not being able to pay her rent, finds herself homeless and alone. Approached in a bar by a man who offers her the use of an empty flat and promises to come and visit her regularly, Selina finds herself alone, and takes to drinking and dancing in her garden, attracting the attention of her neighbours who accuse her of being a prostitute and a nuisance. After a row and the arrival of the police, Selina is taken to prison. Phillips envisages a similar trajectory for Monica Johnson, who after the loss of her child and a period spent in hospital, decides to move to London. The incidents in Rhys's story are very closely followed in the chapter entitled "Alone," where Monica finds herself alone and in need of accommodation. She is assisted by a man she meets in a pub, an actor she vaguely recognizes, who offers her a room in Shepherd's Bush. But, like Selina, Monica experiences isolation and depression and is shunned by her neighbours till the police remove her from the house. Phillips also borrows from Rhys's narrative technique, using a similar first-person narrator and clear, compact style. By layering Monica with Selina, Phillips suggestively introduces yet another intertextual thread in the novel, adding complexity to it, as it invites the reader to reflect on the issue of women's displacement and alienation that inflect both Phillips's and Rhys's narratives.

By way of conclusion, it can be argued that The Lost Child reads as a sophisticated intervention in literary traditions and suggestively reflects Phillips's plurality of literary influences and affiliative relationships. The novel participates in Phillips's ongoing project of retrieving the memory of transatlantic slavery and its legacy, as part of a broader investigation of "the discursive nature of history" (Birat 27) that involves addressing 
literary history. Phillips's narratives, positioned at the intersection of postmodern and postcolonial literature, braid together multiple histories and stories and trace complex transnational trajectories. As a rewriting of a major work in English literature, The Lost Child elaborates on the complex relationship between "postcolonial context and canonical pre-text," "opening up fissures in the supposedly solid foundations" of the source text (Thieme 2). In his exploration of multiple literary voices in the novel, including his own, the author complicates his relationship with his main pre-text, since, by introducing other intertexts (Thieme 7), he can work on multiple affiliative identifications. Phillips is interested in opening up the fissures of Wuthering Heights, and juxtaposes Brontë's novel with Rhys's work, evoked both at a textual and a meta-textual level, while suggestively bringing in episodes of his "life in ten chapters" or traces of an autobiography in progress. And the resulting polyphony of literary voices orchestrated in The Lost Child significantly enriches Phillips's oeuvre, "a many tongued chorus continu[ing] to swell" (Crossing the River 237).

Giovanna BuONNANO

University of Modena and Reggio Emilia, Italy

\section{Works Cited}

Baucom, Ian. Out of Place. Englishness, Empire and the Locations of Identity. Princeton, NJ: Princeton UP, 1999.

BirAt, Kathie. "'Re-visionary Strategies': History and Fiction in the Novels of Caryl Phillips and Wilson Harris." Theory and Literary Creation / Théorie et création littéraire. Ed. Jean-Pierre Durix. Dijon: Editions Universitaires de Dijon, 1999. 21-31.

BRONTË, Emily. Wuthering Heights. 1847. Edited and with an introduction by David Daiches. London: Penguin, 1965.

CalBI, Maurizio. "Vexing Encounters: Uncanniness, Belonging and Alterity in Caryl Phillips's Cambridge." Cross-Cultural Encounters: Identity, Gender, Representation. Eds. Marc Silver and Giovanna Buonanno. Rome: Officina, 2005. 45-55.

Clingman, Stephen. "The Nature of Empathy: An Interview with Caryl Phillips." Journal of Postcolonial Writing. Published online 8 February 2017: 1-23.

Emery, May Lou. "Misfit: Jean Rhys and the Visual Cultures of Colonial Modernism." Jean Rhys. Spec. issue of Journal of Caribbean Literatures 3.3 (Summer 2003): xi-xxii.

Gilroy, Paul. "Cultural Studies and Ethnic Absolutism." Cultural Studies. Eds. Lawrence Grossberg, Cary Nelson and Paula A. Treichler. London: Routledge, 1992. 187-98.

LeDent, Bénédicte. "Is Counter-Discursive Criticism Obsolescent? Intertextuality in Caryl Phillips's Higher Ground". A Talent(ed) Digger. Creations, Cameos, and Essays in Honour of Anna Rutherford. Eds. Hena Maes-Jelinek, Gordon Collier and Geoffrey Davis. Amsterdam: Rodopi, 1996. 301-8.

—. Caryl Phillips. Contemporary World Writers. Manchester: Manchester UP, 2002.

—. "Slavery Revisited through Vocal Kaleidoscopes: Polyphony in Novels by Fred D'Aguiar and Caryl Phillips." Revisiting Slave Narratives. Ed. Judith Misrahi-Barak. Montpellier: Université Paul Valéry Montpellier III, Coll. Les Carnets du Cerpac, 2005. 281-93.

MeYER, Susan. Imperialism at Home. Race and Victorian Women's Fiction. Ithaca: Cornell UP, 1996.

Phillips, Caryl. The European Tribe, London: Faber, 1987.

—. Crossing the River. London: Bloomsbury, 1993.

PHiLLIPS, Caryl, ed., Extravagant Strangers. London: Faber, 1998.

—. A New World Order. London: Secker and Warburg, 2001.

-. Color Me English. Migration and Belonging Before and After 9/11. New York: The New Press, 2011

—. The Lost Child. London: Farrar Straus and Giroux, 2015.

RHYs, Jean. "Let them Call It Jazz." 1960. Tigers are Better-looking. London: André Deutsch, 1968.

Schatteman, René T., ed. Conversations with Caryl Pbillips. Jackson: U of Mississippi P, 2009.

Thieme, John. Postcolonial Con-texts. Writing Back to the Canon. London: Continuum, 2001. 


\section{commonwealth Essays and stupies}

SмIтH, Wendy. "The Lost Child by Caryl Phillips." The Boston Globe, 21 March 2015 <https:// www.bostonglobe.com/arts/books/2015/03/21/book-review-the-lost-child-caryl-phillips/ xuNMdk6CEAwfKGHn3fA4uK/story.html> Consulted 10 February 2017.

Yelin, Louise, "Plural Selves. The Dispersion of the Autobiographical Subject in the Essays of Caryl Phillips." Caryl Pbillips: Writing in the Key of Life. Eds. Bénédicte Ledent and Daria Tunca. Amsterdam and New York: Rodopi, 2012. 57-73. 